perennial herbs, and cattle make war on the species suitable for their food, and at the same time carry with them the seeds of many species adapted to such means of transport. To these causes we must attribute the wide diffusion of many plants, chiefly from southern Europe, introduced by man, either accideatally or intentionally, into the Argentine region and No:th Patagonia. A few of these appear to have spread beyond the bounds of European colonisation, but the majority seem to keep pace with the extension of the white race and of domestic cattle.

This volume, dated I $88 \mathrm{I}$ when it went to press, but not published till 1882 , is very well printed and illustrated by twelve well-executed lithozraph plates, in a manner creditable to the typographic resources of Buenos Ayres, and reflects honour on the admiristration of the republi: and on General Roca, who, as commander of the expedition, deserves the credit of associating with his staff several competent scientific men. We probably owe it mainly to bis influence that the results have been given to the world in a manner so complete and satisfactory.

J. B.

\section{ACROSS THE PAMPAS AND AMONG THE}

\section{$A N D E S^{1}$}

$\mathrm{T}$

$\mathrm{HE}$ interest attaching to the confederation of South American provinces known as the Argentine Republic more than justifies Prof. R. Crawford in the publication of an account of his journeys across the Pampas and the Andes. Some fourteen years ago the Government of the Province of Buenos Ayres, foreseeing the vast importance of a line of railway which would connect the two oceans, entered into an agreement with the firm of Waring Brothers of London to send out a staff of engineers to explore and survey a route for a proposed Transandine railroad. Prof. R. Crawford was given the command, and, with his colleagues, left Liverpool in March I87 I for Monte Video, which was reached after a voyage of a month's duration. On landing, it was soon ascertained that matters were in desperate plight at Buenos Ayres. The frightful epiclemic of yellow fever was still raging, the local Government had proclaimed public holidays and itself migrated to a distance from the doomed city, business of all sorts was suspended, and silence reigned in the streets. Under these circumstances, but for the pluck and energy of Prof. Crawford, the scheme for the survey across the Pampas would have come to an untimely end (that from the Chili side had commenced towards the end of April I $87 \mathrm{I}$ ) ; but he determined it should proceed, and never let the local authorities have any rest until all preliminaries were settled. In the meanwhile the enforced sojourn at Monte Video was not over pleasant. The city was in a state of siege, and it was not for some time after the arrival of the party that a temporary peace was patched up. Weary of the forced delay, Prof. Crawford and some members of his party visited Concordia and made a survey for the Salto Grande Canal. They passed, in their voyage up the Plate, Buenos Ayres, looking in the distance bright and pleasant, though death was stalking through it. In steaming up the Uruguay they saw Liebig's famed extract-of-beef factory at Fray Bentos, and McCall's vast establishment at Paysandu. In an account of a short excursion made from Concordia, we find the following interesting anecdote about the black vulture (Cathartes atratus) of La Plata; perhaps the coolness of the vulture's behaviour is fully equalled by the coolness of the driver in appropriating the stray horse:-

"The roads were very sandy, and the wheels sank deeply into them, making the carriage heavy to draw, so that the driver gladly appropriated a stray horse we met

I "Across the Pampas and the Andes." By Robert Crawford, M.A. With a Map and Illustrations. (London: Longmans, Green, and Co., r88.) upon the way that seemed inclined to join himself to ours, and having extemporised a rude set of harness with some spare pieces carried in reserve, attached him to our team, and drove off in triumph with this new acquisition.

"I was sitting on the box-seat with my gun in hand, when a black vulture came flying past, at which I fired, bringing it to the ground with a broken wing. The strange horse testified his dissatisfaction with the proceeding by the most violent plunging and kicking, that required all the driver's skill and address to overcome.

"When at last he was brought to a state of rest, due, no doubt, in a great measure to exhaustion, the wounded bird occupied our attention by the strange coolness of its proceedings. Regardless alike of our presence and an injured wing, to say nothing of the noise and confusion the horse had created, instead of attempting to escape, it walked quietly up to us, as if about to demand an explanation of the treatment it had received; then mounting deliberately on the wheel of the carriage, hopped in through the open window as composedly as if it were a regular passenger about to occupy an inside seat for which it had been booked in the ordinary manner.

"So offensive was the odour emitted by the unwelcome intruder that we could with difficulty bring ourselves to approach and dislodge it; and when we had done this, the vulture took refuge under the legs of the strange horse, frightening him to such a degree that he began again his strenuous endeavours to get loose, not stopping till he succeeded in smashing the harness to pieces, and escaping from his flapping foe.

"I am afraid that I was not popular that afternoon with my comrades and the driver, for my unlucky shot had entailed upon them much inconvenience and delay, so that it was late when we reached the estancia house."

Just as the survey of the canal was finished, traffic between Monte Video and Buenos Ayres was resumed, and, returning to the former place, the whole expedition left for Buenos Ayres on June 16, 187x. The city was still overwhelmed with gloom. Between 20,000 and 30,000 of its inhabitants had been buried within the few previous months out of a population of only 200,000 souls. Numerous houses had the plague spot still marked upon them, but in a very short time things looked more cheerful, and there were no outward tokens of the plague the city had passed through. Now began the negotiations for the necessary escort to accompany the expedition across the Pampas. While the expenses of the expedition were in great measure to be defrayed by the local Government of Buenos Ayres, it will be remembered that this Government has no national authority, nor could it undertake any outside its own territory, it was therefore necessary for the provincial Government to come to an understanding, which they did, with the national Government and with its neighbouring provinces, and with the Republic of Chili, for the passage of the expedition through these lands and for the supply of a military escort. "Along the whole route," the general commanding on the frontier reports to the President of the Republic (May 20, 187 I), "there will be danger: the Indians were in a state of alarm that the objects of the Survey were to take more and more of their territories from them, and were determined to destroy the members of the expedition when possible," and the general calculated that an adequate force to properly protect the party from all danger should not number less than I 500 men perfectly equipped. Under these circumstances, and after some months' delay, the originally proposed route was abandoned, and a more northern one, in territory likely to be more free from the predatory attacks of the Indians, was adopted, and with a small escort the expedition left Buenos Ayres on August 17, 1871, and took up their quarters at Chivilcoy, I00 miles to the west of it; here final preparations were made for the formidable journey across the Pampas. The Chili expedition in the meantime had, before reaching the summit of the mountains, 
been obliged, owing to heavy falls of snow, to abandon the work, which was not resumed until September. In this month too the preliminary party of the Pampas expedition started, and were followed by the rest of the party towards the end of October. We leave the reader to peruse in the volume itself an account of all the troubles and difficulties that had to be, and were, overcome ere a party of sixty-six persons, not counting the escort, could be started on such a journey across the boundless Pampas.

By the end of November the Indian frontier was reached, the work of the Survey having proceeded well. Water was often scarce, and only procured by sinking wells, which furnished but very moderate supplies. Some very sudden changes of temperature were encountered. Thus, on November 13, "the thermometer, which had hitherto been registering great heats, suddenly fell to $26^{\circ} \mathrm{F}$., converting the water in our tents into ice." Deer (Cervus campestris) and partridge (Nothura maculosa and Rhyncotus rufescens) were abundant. The deer at the season they were met with went about in small herds of from three to seven. As they advanced water became more scarce, and moreover was often muddy. Once when the stock at the disposal of the cngineers' mess was reduced to a small kettle-full, and that heavily charged with sediment, it was resolved as a means both of economising the fluid and making the most of the mud, that it should be made into coffee. Anxiously the little group sat around the camp fire watching the kettle, the water in which was never to boil, for by some unfortunate accident, the particulars of which were never explained, as the subject was one too painful to be talked over, the kettle was overset, and its contents poured out on the resenting flames, amidst a groan of horror from the parched throats around it. In this Indian territory Rheas (Struthio rhea) were numerous, and the young birds were very easily tamed, those captured by the men becoming pets in a few days, and wandering about the camp like young turkeys. The

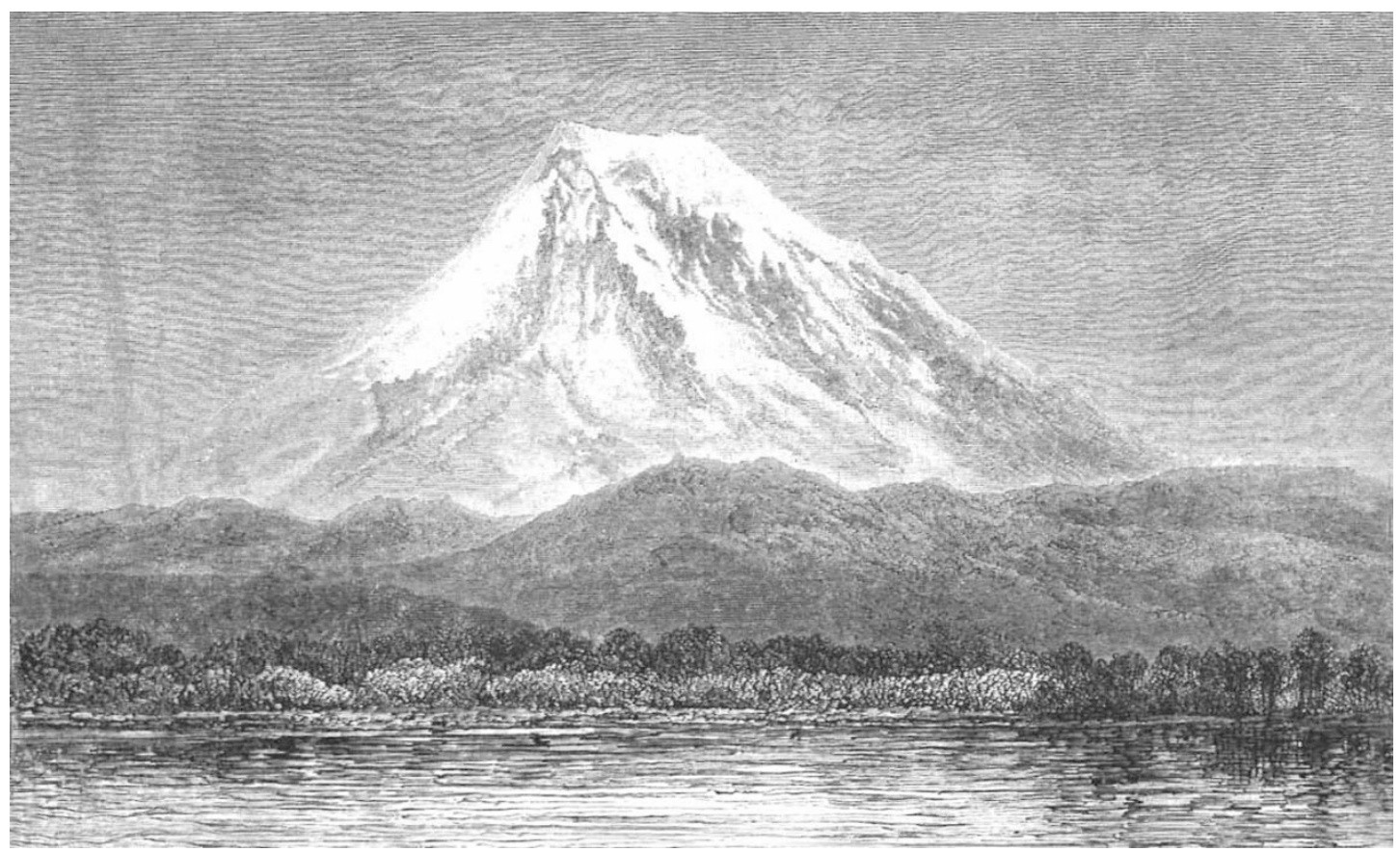

Tupungato, from the River Lujan.

generally careful and prudent engineer-in-chief was here on one occasion so heedless of his own safety that he was nearly coming to grief. One night he passed out of bounds unnoticed, but on attempting to regain the encampment he found his situation most serious, for he was at once challenged by the sentry, who happened to be a Frenchman fresh from the experiences of the FrancoGerman war, and not being satisfied with Prof. Crawford's explanation, he proceeded to present his rifle. Not anxious to serve as a target, the professor, to prevent the sentry from getting him projected on the sky line, fell flat on the ground, and while in that somewhat undignified position, some of the men coming out on hearing the alarm, recognised his voice, and released him, resolving to be more prudent the next time that he wandered beyond range. Several troops of wild horses were met with; they had all flowing manes, and tails that swept the ground. On November 29, an attack in force of the Indians being most imminent, and the military escort being ordered to retire on Fort Media Luna, the surveying operations were most reluctantly discontinued. The last peg was driven well into the ground and covered with a large mound of earth. When thinking of resuming operations, Prof. Crawford demanded an escort of 200 men, but after a promise of fifty, was only eventually furnished with twenty. To continue the survey work with such an escort was quite out of all reason, and the question arose, what was to be done? After all that had been endured and all that had been accomplished, was the expedition to be abandoned? Such a termination woull have been a most painful one to all engaged; Crawford therefore determined to risk everything, and endeavour to accomplish the mission by crossing the Pampas in a compact body, keeping along the line of frontier until the Andes were approached, and then bearing southwards, to ascend their eastern slopes until they should join their colleagues from the Chilian side at the place of rendezvous. This determination they proceeded to carry out on December 6, when Media Luna was left. On the I 8 th the swampy district known as the "Amarga" was reached 
Here the Rio Quinto loses itself in an extensive sandy plain to reappear not far off as the Salado, which river falls into the Plate, about sixty miles south of Buenos Ayres. A couple of days later, near Fort "Nichochæa" the cactus was met with and the potato in blossom. The tubers of the latter were very small, and, when boiled, tasteless. Lakes were now often met with, the water generally sweet, and the lakes encircled by sand-hills. At Fort Sarmiento the Rio Quinto was crossed; it had here cut for itself a channel 300 feet wide through a gravelly soil to a depth of some ten feet below its banks. About December 23 trees became numerous, and the monotony of the ocean-like plain was broken by the appearance of a mountain (El Morro). Here Colonel Roca was in command of a garrison, and at once struck Prof. Crawford as a man most highly gifted by the possession of many qualities not often associated in the same individual. $\mathrm{He}$ has since risen in his profession to be a general, and now as President of the Argentine Republic directs its affairs with wisdom and firmness.

The country now became more interesting, and the Rio Quinto presented well-wooded banks. Christmas Day was spent in camp, the thermometer indicating $\mathrm{IO}_{4}^{\circ} \mathrm{F}$. in the shade. At Villa Mercedes the Rio Quinto runs in a valley it has formed for itself some 1270 yards wide. Here oxen were changed for mules, and the weariness of the delay at this station was aggravated by the great heat of the weather during the day, and the intensity, by contrast, of the cold at night, the thermometer ranging from $107^{\circ} \mathrm{F}$. in the shade during the day to $34^{\circ} \mathrm{F}$. at night. The mules gave great trouble, refusing to carry the baggage carts, and almost bringing the expedition to a close; but again the energy of its head succeeded in getting matters to rights, but not before a journey to San Luis, and procuring there the requisite number of pack mules. San Luis was left on February 3, and Mendoza was reached about the IIth The first sight of the glorious range of the Andes inspired the expedition with a fresh energy.

"The scene which met our tired cyes was one of such magnificence and grandeur as soon dispelled all weariness, and filled us with wonder and amazement. There stood the Andes boldly outlined against the sky, with the mighty 'Tupungato' towering like a giant above the other peaks, its snow-clad summit bathed in gold by the sun's first rays (itself not yet apparent over the horizon), while rosy clouds alternating with crimson and violet of deepest hue, brought out the lights and shades upon the rugged mountain tops, and all below was merged in one vast sea of sombre grey, night's mantle, which the sleeping earth had not yet put aside. Each moment did the picture alter, and every change brought with it some fresh beauty not before perceived, till the sun, rising from the pampas as from the ocean, covered the mountains with a dazzling light, in which the delicate tints and shades of colour disappeared, and last of all the darkness at their base resolved itself into a thin blue cloud like smoke, which hung about them for a while, and then too, was in turn forced to yield and vanish as the rest had done. It was impossible to look on such a scene unmoved, or to find words wherewith to reproduce it to another's eye. Gladly would we have lingered gazing at the view before us, but business, demanding our attention, recalled us to more practical affairs. It was necessary that we should be off without delay; a long and weary journey lying before us. That day we travelled six-andthirty miles, three-fourths of the distance being over a barren sandy soil, destitute alike of grass and water. The day was very hot, and during it all our dogs, which for many months had followed the fortunes of the expedition, disappeared; where they had gone to no one knew, but it was thought that possibly they had sought shelter from the scorching heat under some thick shrubs we passed upar the route, and never afterwards had been able to overtake or find us; or when the cold of night came on, they may have retraced their steps back on the route we took that morning and joined their lot with the first settler they fell in with. Whatever was their fate, we deeply regretted to have lost our faithful followers and friends."

Soon they were up among the Andes into deep ravines among lofty hills, now descending into valleys, and soon afterwards ascending giddy heights. An extinct volcano, now a beautiful mountain called the "Cerrito Diamante," was passed; some thirty miles from it a rill of a yellowishwhite fluid, like petroleum, issuing from the mountain-side at a considerable height, was discovered. The source from which it flowed was at the junction where a hard metamorphic rock interspersed with small augite crystals overlay a stratum of volcanic tuff. It was in form like a crater of a volcano, and full of a black bituminous matter, hot and sticky, which could be stirred to a depth of about 18 inches. Floundering in it was a polecat, which had been enticed to its fate by a bird caught in this natural birdlime. The overflow was 2 or 3 feet wide, and as it spread out it became of an asphalt-like form. Two other little birds were found entangled in the stream, and on being released both feathers and skin came off. Possibly they had mistaken the stream for water. A further search revealed many bird and small mammalian skeletons embedded in the mass, possibly a puzzle for some palæontologist in days to come. After leaving the River Atuel sandstone and limestone strata were met with, and on February 29 their colleagues from the Pacific coast who had crossed the Andes by the Planchon Pass were met. The combined party rested a few days in the highland valley of Las Leñas Amarillas, where guanacos abounded. The watershed of this district was reached at a level of 9200 feet above the sea, the scenery being of surpassing beauty, and the Andes are described as having no lovelier spot than this secluded "Valle Hermoso." Here a good deal of landsurveying was accomplished, and also in the region of the Rio Grande. In the middle of March the passage of the Andes was begun via the Planchon Pass. The attempt to cross by the head of the Rio Grande was frustrated by the dangerous illness of a colleague when a height of about Ir,ooo feet had been attained, and fearing the consequences if they bore him to the summit (I000 feet higher), they retraced their steps and went over by the Planchon Pass, 8225 feet above sea-level. On the descent silver and copper mines were passed. After five months of hardships, a day at the lovely baths of Cauquenes was thoroughly enjoyed, and on March 25 the party arrived at Santiago de Chili, described as a city which for its position cannot be surpassed in grandeur and the magnificence of its surroundings. After a fortnight's sojourn here, Valparaiso was reached by rail, from whence, proceeding through the Magellan Straits, Monte Video was reached, and thence home.

All through the narrative the reader's interest is sustained, and the author might often indeed have ventured on further details without the least risk of being tedious. The trials and hardships undergone are very slightly dwelt upon, but they must have been many and great. On the result of his labours, and on this pleasant narration of some of the chief incidents of his travels, we heartily congratulate $\mathrm{Mr}$. Crawford, whom we are also glad to find once more located within the walls of his ancient University, laying the varied experiences of his life before the engineering classes of Trinity College, Dublin.

In a most valuable and important series of appendixes we have an excellent account of the peaks and passes of the Andes, which seem in every way worthy of the Alpine clubs of Europe ; a most important essay on the Argentine Republic, its position and extent, its Indian frontier and invasions, its colonies and railways-a Republic with a great future before it, and one in which our British interests are largely involved. 